Schulich School of Law, Dalhousie University

Schulich Law Scholars

The Precautionary Principle and Marine Environmental Protection: Slippery Shores, Rough Seas, and Rising Normative Tides

David VanderZwaag

Follow this and additional works at: https://digitalcommons.schulichlaw.dal.ca/scholarly_works

Part of the Environmental Law Commons 


\title{
The Precautionary Principle and Marine Environmental Protection: Slippery Shores, Rough Seas, and Rising Normative Tides
}

\author{
DAVID VANDERZWAAG \\ Marine and Environmental Law Programme \\ Dalhousie University \\ Halifax, Nova Scotia, Canada
}

\begin{abstract}
Law and policy implications of the precautionary principle in the field of marine environmental protection are explored in this paper in a three-part analysis. First, seven slippery aspects of the precautionary principle are highlighted, including confusion in terminology, definitional variations, definitional generalities, the spectrum of precautionary measures available, ongoing philosophical tensions and competing socioeconomic interests, debate over who should be responsible for making precautionary decisions, and limited interpretation by international tribunals. Second, the rather feeble precautionary responses to the tempestuous issues of climate change, hazardous chemicals, and overfishing are described. Third, the potential for the precautionary principle to synergize with human rights norms, such as the emerging right to a healthy environment, and other principles of sustainable development is discussed.
\end{abstract}

Keywords climate change, fisheries, ocean governance, marine environment, precaution, sustainable development

\section{Introduction}

The precautionary principle is surging over the shores of marine environmental protection. ${ }^{1}$ Almost every international environmental agreement and declaration in the past decade has voiced the notion that when an activity, such as proposed pollution or a coastal development, carries the potential for serious environmental harm, decision makers should err on the side of caution. ${ }^{2}$ Scientific certainty of dead fish or diseased bodies

Received 28 July 2001; accepted 17 September 2001.

The author would like to acknowledge the research assistance of Stacey Ferrara and Melanie MacLellan as well as the financial support of the Social Sciences and Humanities Research Council of Canada (SSHRCC) for ongoing research in the area of toxic chemicals management in light of sustainable development principles and human rights norms. This paper is an expanded version of a draft presented at the SEAPOL Inter-Regional Conference on Ocean Governance and Sustainable Development in East and Southeast Asian Seas: Challenges in the New Millennium, 2123 March 2001, Bangkok, Thailand. A summary version was also presented at a panel on Oceans Explorations (April 6, 2001, Halifax, Nova Scotia), sponsored by CBC Radio One, Fisheries and Oceans Canada, and the International Oceans Institute of Canada. The summary text is available at http://www.OceansCanada.com/discussion/htmdocs/oe2001.htm.

Address correspondence to David VanderZwaag, Dalhousie Law School, 6061 University Avenue, Halifax, NS, Canada B3H 4H9. E-mail: David.VanderZwaag@dal.ca 
should not be waited for; precautionary actions should be taken now. From climate change to biodiversity protection, precautionary measures are being urged. ${ }^{3}$

A prime reason for the international popularity of precaution is its reflection of common sense notions evident in numerous cultures. The precautionary principle promises to give practical effect to such sayings as, "better safe than sorry"; "an ounce of prevention is worth a pound of cure"; "a stitch in time saves nine."4

While numerous other normative principles, such as intergenerational equity, public participation, community-based management, integration, and ecosystem management are driving marine environmental protection reforms, ${ }^{5}$ the precautionary principle is often referred to as one of the most fundamental principles given its far-reaching implications for decision making. ${ }^{6}$ The principle promises to be the "big balancer" in sustainable development by reversing the burden of proof to proponents of change/ development to demonstrate some level of acceptability or safety. ${ }^{7}$

However, getting a clear "normative fix" on the precautionary principle is difficult. The principle is often called "elusive" given its general nature and still limited international implementation. ${ }^{8}$ The law and literature relating to the precautionary principle has been described as in "disarray," with great confusion over meaning and detachments from relevant social science and legal literature. ${ }^{9}$

Three images, explored in this article, help capture the present law and policy reality, namely slippery shores, rough seas, and rising normative tides. The precautionary principle remains slippery for various reasons, including widely varying definitions, ongoing philosophical debates, and the numerous precautionary measures possible. The principle is also facing a rough ride in at least three key areas of marine environmental protection. Weak, rather limited embraces of precaution have occurred in addressing the crises of climate change, hazardous chemicals, and overfishing. The principle also has potential for synergizing with other normative currents, including developments in human rights law, such as the emerging right to a healthy environment and the evolving environmental rights of indigenous peoples, and other principles of sustainable development like intergenerational equity.

\section{Slippery Shores}

The precautionary principle is slippery in at least seven ways. Uncertainties arise from terminology, definitional variations, definitional generalities, the spectrum of precautionary measures, ongoing philosophical debates and differing socioeconomic interests, vagueness over who should be responsible for precautionary decisions, and limited interpretation by international tribunals. A discussion of national legislative variations ${ }^{10}$ and differing interpretations by national courts and tribunals, ${ }^{11}$ another slippery aspect, is beyond the scope of this article

\section{Terminology}

Debate has occurred over the proper terminology, precautionary principle, or precautionary approach, and whether the terms principle and approach have differing meanings. The United States and Canada, in their trade challenge against the European Union's ban on beef from countries using growth hormones, argued for the term precautionary approach as it denotes a softer, nonbinding nature. ${ }^{12}$

In the international fisheries management field, initiatives led by the Food and Agriculture Organization (FAO), such as the FAO Code of Conduct for Responsible 
Fisheries, ${ }^{13}$ have preferred precautionary approach since the term is viewed as avoiding extreme implications such as reversing the burden of proof to fishers to show no environmental harm and the imposition of moratoria on fishing activities. ${ }^{14}$

Some commentators have suggested the terms principle and approach are essentially synonymous. ${ }^{15}$ The Rio Declaration on Environment and Development ${ }^{16}$ itself uses both the terms principle and approach. ${ }^{17}$ To ensure the potential distinction is kept in mind, some authors have used the wording precautionary principle/approach. ${ }^{18}$

\section{Definitional Variations}

Over a dozen different definitions of the precautionary principle occur in international conventions, declarations, and documents. ${ }^{19}$ Therefore, it is difficult to "nail down" the exact parameters, for example, what should trigger the application of the principle.

The variations in the trigger may be seen in the Rio Declaration and the Ministerial Declaration of the Second Conference on the Protection of the North Sea (The London Declaration). The Rio version of precaution calls for application of the precautionary approach where an activity threatens "serious or irreversible damage," 20 while the London Declaration would trigger precaution on the basis of an activity "likely to cause damage or harm." 21

\section{Definitional Generalities}

Perhaps the most widely used articulation of the precautionary principle/approach is drawn from Principle 15 in the Rio Declaration:

In order to protect the environment, the precautionary approach shall be widely applied by States according to their capabilities. Where there are threats of serious or irreversible damage, lack of full scientific certainty shall not be used as a reason for postponing cost-effective measures to prevent environmental degradation.

The definition is loaded with generalities. What exactly does serious and irreversible harm mean? What is lack of full scientific certainty? What are cost-effective measures? The wording "according to their capabilities" suggests precaution may be extremely malleable. ${ }^{22}$

Academic efforts to clarify the meaning of the precautionary approach have also left considerable fuzziness. For example, core elements of precaution have been suggested:

- willingness to take action in advance of formal proof,

- proportionality of response,

- provision of ecological space and margins of error,

- recognition of the well-being interests of nonhuman entities,

- a shift in the onus of proof onto those who propose change,

- concern for intergenerational impact on future generations,

- recognition of the need to address ecological debts. ${ }^{23}$

Key questions remain with the general checklist. For example, what type of proof should proponents of change be required to establish before approval is granted ${ }^{24}$ How 
wide should margins of error be $?^{25}$ How much value should be accorded to species and habitats in light of human needs for food and resources? ${ }^{26}$

\section{Spectrum of Precautionary Measures}

The precautionary principle/approach is also slippery because of the wide spectrum of available management measures. Direct and extreme measures to encourage precaution include outright prohibitions on certain human activities, such as nuclear technology or new aquaculture developments; designation of "no take" areas; and "reverse listing" for pollutants or wastes where only pollutants/wastes listed on a "safe list" would be allowed to be used or discharged. ${ }^{27}$

An example of a direct/extreme approach at the international level is in ocean dumping, where the 1996 Protocol $^{28}$ to the London Convention $1972^{29}$ requires a precautionary reverse listing approach where only wastes listed on a "safe list" may be disposed of at sea $^{30}$ and only after government regulators require a waste assessment. ${ }^{31}$

Direct but less extreme measures include requiring pollution prevention or waste minimization plans as a precondition to licensing industrial operations ${ }^{32}$ and mandating decision makers to apply the precautionary principle/approach without strict guidelines. ${ }^{33}$ Indirect measures include requiring environmental impact assessments of proposed projects and proposed governmental programs, plans, and policies to identify environmental impacts and mitigation options; ensuring strict or absolute liability regimes for pollution damage; and encouraging public participation in all aspects of decision making to provide "common sense" perspectives. ${ }^{34}$

Practical implications of the precautionary approach to fisheries management have also been subject to debate with numerous management measures possible. ${ }^{35}$ Those measures include, among others,

- establishing cautious quotas;

- terminating open access fisheries and developing management plans within a certain time frame;

- prohibiting or strictly regulating destructive fishing techniques and promoting selective, environmentally friendly fishing technologies/methods;

- requiring environmental assessment before opening a new fishery;

- including environmental nongovernmental organizations (NGOs) and nonfishery users in fisheries management;

- promoting consideration of fisheries in integrated coastal area management

- allowing fish stocks to spawn at least once;

- setting aside marine protected areas.

\section{Differing Viewpoints and Socioeconomic Interests}

The conceptual shores of precaution are also slickened by competing philosophical and cultural values and socioeconomic interests, where persons often disagree over how precautionary society should be. ${ }^{36}$ Persons with an ecocentric worldview will likely favor strong precautionary measures based upon a risk-adverse attitude ${ }^{37}$ and a belief in individual rights, such as a right to a clean, healthy environment. ${ }^{38}$ Persons with a transcendent worldview are likely to be more risk-taking, open to making cost-benefit or risk-benefit tradeoffs and more amenable to reliance on scientific proof. ${ }^{39}$ Cultural attitudes may also vary, as exemplified by differing risk perceptions towards genetically modified organisms in Europe and the United States. ${ }^{40}$ 
One of the major unresolved tensions in the precautionary debate is the appropriate roles for science and economics versus the roles of public beliefs and perceptions. ${ }^{41}$ One of the reasons why the precautionary principle/approach has become so controversial is that it challenges the dominant approach to public administration, which has emphasized technical rationality and the scientific-analytical mindset. ${ }^{42}$ One of the central battlefields has been and will likely continue to be over the appropriate role of scientific risk assessment in decision making. ${ }^{43}$ Uncertainties continue over the extent to which countries may prohibit or restrict trade, for example, in genetically modified foods, based upon sociocultural risk perceptions rather than scientific assessment. ${ }^{44}$ The appropriateness of cost-benefit and risk-benefit analysis is also subject to considerable debate. ${ }^{45}$

Personal interests in resource exploitation may also complicate the picture with socioeconomic needs and demands fuelling less precautionary viewpoints. ${ }^{46}$ For example, a proponent of offshore mineral development or aquaculture expansion may be mesmerized by the benefits, while traditional fishers may rally over the potential costs. ${ }^{47}$

\section{The Appropriate Decision Maker or Interpreter}

A further slippery issue area relating to precaution is sorting out who should be endowed with making precautionary determinations and judgments. ${ }^{48}$ Some might argue that politicians, given their elected status, are the best arbiters of competing social values. Expert administrators might be supported because of their special skills and knowledge. Others might argue for judges to play a proactive role in interpreting the content of precaution given the lobbying pressures and short-term election interests facing politicians and the need to foster justice, including ecosystem values. ${ }^{49}$ The creation of new precautionary institutions and mechanisms might also be argued for, such as independent regulatory boards or agencies to oversee risk assessments and make risk management decisions. ${ }^{50}$ More participatory mechanisms, such as multistakeholder task forces and alternative dispute resolution techniques, may also be envisaged. ${ }^{51}$

\section{Limited Interpretation by International Tribunals}

Precautionary interpretation by international tribunals has been limited. In New Zealand v. France, ${ }^{52}$ the majority of the International Court of Justice dismissed the case on jurisdictional grounds and did not address New Zealand's arguments regarding the precautionary principle. New Zealand had argued that France, before proceeding with further underground nuclear testing in the South Pacific, should be required to undertake additional environmental impact assessment and should bear the burden of proof to show in advance that its activities would not cause environmental contamination. In the Legality of the Threat or Use of Nuclear Weapons Advisory Opinion,,$^{53}$ Judge Weeramantry, in a dissenting opinion, indicated that nuclear weapon use would violate a number of principles of environmental law, including the precautionary principle, but no detailed analysis of precaution was provided. ${ }^{54}$ In the Hungary v. Slovakia case, ${ }^{55}$ Hungary argued that the precautionary principle obliges all countries to prevent environmental damage and that Hungary, therefore, should be able to terminate a 1977 Treaty with Czechoslovakia (later Slovakia) which called for the construction of a series of joint barrages along the Danube river with uncertain environmental consequences. The Court, while not rejecting the relevance of the precautionary principle, avoided a detailed discussion of its legal implications. ${ }^{56}$

In the Southern Bluefin Tuna cases, ${ }^{57}$ involving legal action by Australia and New 
Zealand seeking to stop Japan from unilaterally increasing catch levels of southern bluefin tuna beyond previously agreed upon treaty allocations, the International Tribunal for the Law of the Sea (ITLOS) granted provisional measures ordering Japan to refrain from further "experimental fishing" (except with the agreement of the parties or under an experimental catch counted against its annual quota). While ITLOS's decision did not expressly mention the precautionary principle, ${ }^{58}$ at least two judges indicated the provisional measures ordered were based on precaution. ${ }^{59}$ Judge Laing raised the question of whether the precautionary principle should reverse the onus of proof to the party wishing to increase catch levels, but he felt the question should be left to full arbitration for consideration. ${ }^{60}$ Unfortunately, the arbitral tribunal found that it lacked jurisdiction in the case and, therefore, the merits of precaution were not addressed. ${ }^{61}$

\section{Rough Seas}

Three areas of marine environmental protection stand out for the cautious approaches to precaution being taken in light of the large threats to the marine environment. States have yet to forge effective and firm precautionary approaches to climate change, hazardous chemicals, and overfishing. ${ }^{62}$

\section{Climate Change}

The threats to the marine environment of global warming are broad and serious. Coral bleaching, associated with warming ocean temperatures, has affected all tropical regions of the globe, including the Andaman Sea off Thailand, ${ }^{63}$ and in some areas of the Indian Ocean mortality of reefs from bleaching has neared $90 \% .{ }^{64}$ Island States, such as the Maldives and Marshall Islands, face major inundations, and vast areas of low-lying coastal states are predicted to experience increased flooding, accelerated erosion, loss of wetlands and mangroves, and seawater intrusion into freshwater sources. ${ }^{65}$ Potential damages to infrastructure in coastal areas from sea level rise have been predicted to be tens of billions of dollars for individual countries, for example, Vietnam, Egypt, and Poland. ${ }^{66}$ The Arctic Ocean has reportedly lost some $40 \%$ of its sea-ice thickness in recent decades, ${ }^{67}$ and the increasing ice melt has raised scientific concerns over the possible breakdown of the global heat pump system. Warmer, less saline ocean waters in the Arctic may disrupt the global current system, driven by sinking cold waters, from the North with negative effects on various countries, especially in Scandinavia and Russia. ${ }^{68}$

While skeptics of the human causes of climate change still remain, ${ }^{69}$ the Intergovernmental Panel on Climate Change (IPCC), in its release of a third assessment report in 2001, was quite conclusive as to the growing certainty of greenhouse gas emissions from human sources being a major contributor to global warming. The IPCC stated: "In light of new evidence and taking into account the remaining uncertainties, most of the observed warming over the last 50 years is likely to have been due to the increase in greenhouse gas concentrations." 70

Strong precautionary approaches to climate change have yet to be worked out. The Framework Convention on Climate Change itself adopted a weak, utilitarian version of precaution $^{71}$ and the subsequent Kyoto Protocol ${ }^{72}$ represents only a feeble response. Developed countries accepted rather minimal reduction commitments for greenhouse gas emissions, an overall target of at least 5\% from 1990 levels by 2008-2012, and many developed countries are actually increasing emissions rather than cutting back. ${ }^{73}$ In March 2001, the United States administration rocked the Kyoto boat by announcing 
its intention not to ratify the Protocol because of the Protocol's exemption of developing countries from reduction commitments and potential damage to the U.S. economy. ${ }^{74}$

Although the Kyoto Protocol has been at least partly salvaged through political commitments under the Bonn Agreements, ${ }^{75}$ and working out some of the rules for the flexibility mechanisms (emission trading, joint implementation and the clean development mechanism) at the Seventh Conference of the Parties to the United Nations Framework Convention on Climate Change in Marrakesh, Morocco in November $2001,{ }^{76}$ the Protocol still likely faces a rough future. Second commitment period allocations remain to be negotiated. Developing countries have not committed to reductions in greenhouse gas emissions. While key parameters of a compliance regime have been agreed to, including a compliance committee having facilitative and enforcement branches, it is the prerogative of the Conference of the Parties serving as the meeting of the Parties to the Kyoto Protocol to decide the legal form of compliance procedures and mechanisms. Administrative and financial complexities surrounding the flexibility mechanisms may divert attention from broader issues such as the critical need to invest much more in research and development of renewable energy sources and the need to promote decentralized and less consumptive societies. ${ }^{77}$

\section{Hazardous Chemicals}

The threats of hazardous chemicals in the marine environment are also substantial. Persistent organic pollutants (POPs), including various pesticides such as dieldrin, DDT, toxaphene, chlordane, as well as industrial compounds (PCBs) and combustion byproducts (dioxins and furans), are found in all the world's oceans. ${ }^{78}$

Their ability to bioaccumulate and persist in the environment raise carcinogenic, reproductive, and other threats to both humans and marine wildlife. ${ }^{79}$ Of special concern is the long-range transport from North America, Europe, Russia, and Asia of POPs and heavy metals (such as cadmium and mercury from coal burning and other industries) into the Arctic, which acts as a pollutant sink. ${ }^{80}$ Indigenous peoples, highly dependent on country foods, are especially at risk given the tendency of POPs to concentrate in the fatty tissues of wildlife, and levels of POPs have been found to be 10 to 20 times higher in northern residents than in those in the South. ${ }^{81}$

Global responses to date have been fragmented and feeble. ${ }^{82}$ The 1998 Convention on the Prior Informed Consent Procedure for Certain Hazardous Chemicals and Pesticides in International Trade ${ }^{83}$ does not prohibit trade in hazardous chemicals banned or severely restricted by countries, but tries to facilitate trade subject to a prior informed consent (PIC) procedure. For the 31 chemicals listed as subject to PIC, exporting states must ensure importing states receive notice and consent to proposed chemical shipments. ${ }^{84}$ The Convention has not yet entered into force and had only 16 ratifications as of 1 September 2001 of the required 50 ratifications for entry into force. ${ }^{85}$ No global convention governs heavy metals. The Global Programme of Action for the Protection of the Marine Environment from Land-Based Activities does set out national, regional, and global priority actions for POPs and heavy metals, but the document is largely aspirational without firm financing to assist countries in addressing problems. ${ }^{86}$

The Stockholm Convention on Persistent Organic Pollutants,${ }^{87}$ while recognizing the precautionary principle as an objective, may be described as a case of chemical tinkering. ${ }^{88}$ The Convention, adopted in May 2001, only addresses an initial 12 chemicals (the "dirty dozen") ${ }^{89}$ and is not firm on elimination. For example, countries are required to make "determined efforts" to phase out PCB-containing equipment by $2025,{ }^{90}$ 
and DDT use will be allowed to continue for disease control..$^{91}$ Specific exemptions up to five years may be registered by parties for limited uses of many of the chemicals listed for elimination in Annex A. ${ }^{92}$ Each party is required to take measures to reduce total releases of unintentionally produced POPs listed in Annex C (dioxins, furans, hexachlorobenzene, PCBs), but the goal is stated as "minimization and, where feasible, ultimate elimination." ${ }^{93}$ The Convention promotes a risk assessment approach to adding new POPs for control which does not bode well for prompt and strong precautionary actions. ${ }^{94}$ The Convention is not a comprehensive chemicals treaty ${ }^{95}$ addressing the huge number of synthetic chemicals available for commercial use, estimated between 50,000 and 100,000 , with some 1,000 new chemicals entering the economy each year. ${ }^{96}$

A time lag for entry into force is also likely of at least 3-4 years. The Convention requires 50 ratifications. ${ }^{97}$

Negotiation of a comprehensive chemicals convention is not on the immediate political horizon. The United Nations Environment Programme (UNEP) has emphasized the need for enhanced coherence and efficiency among international chemical activities and has stopped short of calling for a proactive and comprehensive treaty. At the $21 \mathrm{st}$ session of UNEP's Governing Council, the Governing Council in decision 21/7 on Chemicals Management merely requested the Executive Director, in consultation with Governments, the Inter-Organization Program for the Sound Management of Chemicals, the Intergovernmental Forum on Chemical Safety, and other relevant organizations and stakeholders, to examine the need for a strategic approach to international chemicals management and to prepare a report for consideration by the Governing Council/Global Ministerial Environmental Forum in 2002.98

\section{Overfishing}

Dwindling fish stocks, linked with frail fisheries management, ${ }^{99}$ is a further crisis area where the precautionary approach is facing major challenges. ${ }^{100}$ Many of the world's major fish stocks have been overexploited or are being fully exploited. ${ }^{101}$ Illegal, unreported, and unregulated fishing in world fisheries is a major concern in both national zones of jurisdiction and on the high seas. ${ }^{102}$ Excess fishing capacity, by-catch, and discarding of fish at sea continue to be identified in the Secretary General's Report to the UN General Assembly on Oceans and the Law of the Sea as grave issues for the international community. ${ }^{103}$

The precautionary approach has crept into fisheries management generally through the FAO Code of Conduct for Responsible Fisheries, which was adopted in 1995. ${ }^{104}$ Article 6.5 in the general principles section provides:

States and sub-regional and regional fisheries management organizations should apply the precautionary approach widely to conservation, management and exploitation of living aquatic resources in order to protect them and preserve the aquatic environment, taking into account the best scientific evidence available. The absence of adequate scientific information should not be used as a reason for postponing or failing to take measures to conserve target species, associated or dependent species and non-target species and their environment.

Article 7.5 spells out further specifics for precautionary implementation. States are urged to determine target reference points (a desirable level of fishing) and limit refer- 
ence points (conservation levels not to be exceeded) as well as management actions to be taken if target or limit reference points are exceeded. For new or exploratory fisheries, states are urged to adopt as soon as possible cautious conservation and management measures, including catch and effort limits. States are also called upon to adopt emergency conservation and management measures if a natural phenomenon has a significant adverse impact on the status of living aquatic resources.

Additional technical guidelines on the precautionary approach to capture fisheries ${ }^{105}$ highlight the major concerns of fishing nations not to be bound by extreme precautionary measures. While the guidelines urge all fishing activities be subject to prior review and authorization, including management plans, ${ }^{106}$ the guidelines are not explicit on the burden and standard of proof. The guidelines call for the "appropriate placement of the burden of proof" 107 but avoid a clear statement of allocation. No concrete standard of proof is suggested. Instead a flexible approach is recommended: "The standard of proof to be used in decisions regarding authorization of fishing activities should be commensurate with the potential risk to the resource, while also taking into account the expected benefits of the activities." 108 The requirement for a proponent of fishing to establish "no harm" is essentially rejected through the statement: "although the precautionary approach to fisheries may require cessation of fishing activities that have potentially serious adverse impacts, it does not imply that no fishing can take place until all potential impacts have been assessed and found to be negligible."109

The 1995 UN Convention on Straddling Fish Stocks and Highly Migratory Fish Stocks, ${ }^{110}$ while requiring Parties to apply the precautionary approach, ${ }^{111}$ also displays a cautious embrace of precaution. A main thrust of the Convention is to require states and regional fisheries organizations to adopt precautionary target and limit references with agreed upon management actions should limits be exceeded. The Convention at least partially promotes a quantification and expert systems approach to fisheries management by requiring limit reference points to be based at a minimum on maximum sustainable yield (MSY). The Convention leaves precautionary implementation details to be worked out largely by subregional and regional organizations. Regional fisheries organizations, such as the Northwest Atlantic Fisheries Organization (NAFO), have largely focused on scientific modelling and debating of reference points without a broader discussion of alternative fisheries management approaches. ${ }^{112}$ The issues of burden of proof shifting ${ }^{113}$ and standard of proof are not being emphasized. ${ }^{114}$

\section{Rising Normative Tides}

While various forces may combine to weaken and narrow the normative implications of precaution, such as political skepticism ${ }^{115}$ and institutional favoritism toward scientific rationality, ${ }^{116}$ two broad currents in international law promise to strengthen the precautionary principle, although the "tidal heights" remain uncertain. Human rights relating to the environment, such as the right to a healthy environment, the right of children to a clean environment, and indigenous rights to environmental protection, continue to evolve and may add pressure for strict precautionary measures. The concept of sustainable development, even though controversial ${ }^{117}$ and amorphous, ${ }^{118}$ has spawned or at least popularized other principles, ${ }^{119}$ including intergenerational equity, polluter pays, public participation, community-based management, integration, and ecosystem management, which are likely to increasingly synergize with precaution. 


\section{Human Rights Developments}

While no global treaty or declaration explicitly recognizes a right to a healthy environment ${ }^{120}$ various wellsprings may nourish normative development. Over 50 national constitutions have entrenched some form of right to environmental protection. ${ }^{121}$ Various cases and commentators have suggested a right to a healthy environment may be inherent in other rights ${ }^{122}$ such as rights to life, liberty, and security of person found the International Covenant on Civil and Political Rights, ${ }^{123}$ or the right of everyone to the enjoyment of the highest attainable standard of physical and mental health in the International Covenant on Economic, Social and Cultural Rights. ${ }^{124}$ Draft Principles on Human Rights and the Environment would go further and recognize various rights, including the "right to a secure, healthy and ecologically sound environment" and the "right to freedom from pollution" that threatens life or health. ${ }^{125}$

The right of the child to a clean environment is receiving increased commentary, ${ }^{126}$ and various provisions in the 1989 Convention on the Rights of the Child ${ }^{127}$ may support arguments for such a right. For example, Article 24 calls upon Parties to "recognize the right of the child to the enjoyment of the highest attainable standard of health" and to provide "adequate nutritious foods and clean drinking-water, taking into consideration the dangers and risks of environmental pollution. . .."128

The relationship between the precautionary approach and indigenous rights and practices is also an evolving field of inquiry ${ }^{129}$ and one can expect indigenous groups to use various arguments to support strong environmental protection measures. ${ }^{130}$ While various indigenous rights may be claimed, ${ }^{131}$ the right to environmental integrity may be drawn from the Biodiversity Convention ${ }^{132}$ and the UN Draft Declaration on the Rights of Indigenous Peoples. ${ }^{133}$ The latter, in Article 28, provides that "Indigenous Peoples have the right to the conservation, restoration and protection of the total environment and the productive capacity of their lands, territories and resources, as well as to assistance for this purpose from States and through international cooperation. . . ."134

While considerable controversy has arisen over human right approaches ${ }^{135}$ to environmental protection, particularly over such issues as whether such rights are substantive or procedural ${ }^{136}$ and the precise content of rights, ${ }^{137}$ rights-based arguments are likely to be increasingly linked with the precautionary principle/approach. ${ }^{138}$ The notions of a clean, healthy environment support strong versions of precaution, such as virtual elimination of toxic substance discharges; phase-outs and substitutions of hazardous substances; and a reverse listing approach to chemicals management. ${ }^{139}$

With difficulties remaining over the ability of individuals to enforce human rights at the international level, ${ }^{140}$ it seems likely that judicial review, linking human rights and precaution, will increasingly be sought at the national level. ${ }^{141}$ Recent cases from the Supreme Court of Canada appear to have set the stage for such linking, ${ }^{142}$ with the Court indicating a liberal attitude towards incorporating international law norms into domestic law through a contextual approach to statutory interpretation and judicial review of administrative decisions. ${ }^{143}$

\section{Synergies with Other Principles of Sustainable Development}

The precautionary principle/approach does not "swim alone." Various other principles of sustainable development promise to affect the normative evolution of precaution. ${ }^{144}$ For example, intergenerational equity supports the notion of long-term planning and placing the burden on proponents of change to consider long-term environmental and 
cultural impacts. ${ }^{145}$ Public participation may be central to precaution in that public perceptions of risk and acceptability are given a voice. ${ }^{146}$ Community-based management supports the movement from centralized management to new forms of community regulation based on sustainable community economies. ${ }^{147}$ The "polluter pays" principle, through the imposition of strict and absolute liability regimes, may push industries towards greater pollution prevention and precaution. ${ }^{148}$

The integration principle may also nourish precaution. For example, the need to integrate fisheries management with broader coastal area management has been recognized in Article 10 of the Code of Conduct for Responsible Fisheries. Additional Technical Guidelines on Integration of Fisheries into Coastal Area Management ${ }^{149}$ recognize the need for various adaptations of the precautionary approach, ${ }^{150}$ including prohibitions on activities in narrow circumstances: "If the outcome of an activity is totally uncertain in the sense that even the range of possible outcomes is unknown, the guiding rule should be to avoid activities that might have irreversible consequences since their potential costs are incalculable." 151

The principle of ecosystem-based management may also be closely linked to the precautionary principle. ${ }^{152}$ Given the complexities of ecosystems and associated scientific uncertainties, the ecosystem approach has numerous implications for marine management, including the need to expand conservation efforts beyond target fish stocks to marine biodiversity health; ${ }^{153}$ the need to establish no-take reserves in order to study the true ecosystem effects of fishing and other activities; ${ }^{154}$ the need for effective monitoring of fisheries and ecosystems and separation of scientific institutions from management; ${ }^{155}$ and the need to protect threatened and endangered marine species. ${ }^{156}$

The overall concept or principle of sustainable development may itself, of course, influence precautionary decision-making. ${ }^{157}$ Given the need to balance environmental, economic, and social equities, a shift from prescriptive to adaptive management has been urged. ${ }^{158}$ Justice Weeramantry, in his Separate Opinion in the Hungary v. Slovakia case, viewed the principle of sustainable development as a vehicle for reconciling the principles of right to development and the right to environmental protection. ${ }^{159} \mathrm{He}$ indicated that there is a duty to ensure that development projects do not significantly damage the environment. ${ }^{160}$

The potential for the concept of sustainable development/management to modify the potential harshness of precaution by allowing limited developments is demonstrated in a couple of New Zealand aquaculture cases. In Trio Holdings v. Marlborough District Council, ${ }^{161}$ the Planning Tribunal, applying a precautionary approach, substantially curbed a marine farming proposal by requiring deletion of a habitat area important to a threatened species (king shag) and refusing consent for mussel farming with related impacts of shell litter and feces. The Tribunal indicated that allowing limited sponge farming for antitumor drug development would be in accord with the concept of sustainable management. In Pigeon Bay Aquaculture Ltd. v. Canterbury Regional Council, ${ }^{162}$ the Environment Court allowed two mussel farming proposals to proceed but refused consent for the growing of dredge oysters and scallops due to the lack of evidence regarding environmental effects.

\section{Conclusion}

A number of images help capture the relationship of the precautionary principle to marine environmental protection. The principle has created "slippery shores" where it is difficult to get a firm conceptual grip for numerous reasons, including the broad array of 
precautionary measures possible, the ongoing philosophical debates over how precautionary societies should be, and lack of clarity in how to institutionalize precaution in law and policy. The precautionary principle is facing "rough seas" in trying to adequately address climate change, hazardous chemical risks, and overfishing, with strong political and economic waves hindering strong precautionary courses. Human rights relating to the environment and various principles of sustainable development are "rising tides" promising to synergize with precaution in normative evolution.

The precautionary principle is not a panacea. The principle promises little in addressing some of the underlying causes of environmental degradation, population growth, poverty, and overconsumption. The commodification of nature, fuelled by market economies and globalization pressures, continues with hard-to-counter assumptions of industrialism, managerialism, and scientism. ${ }^{163}$ The principle is still in its infancy, with few countries actually implementing the principle in legislation and limited public education and debate. Even if precaution is embraced in law, lack of political will and limited human and financial resources may hinder implementation. Precautionary standard-setting at the international level is thwarted by state sovereignty concerns and the lack of effective global governance, such as an empowered world environment organization. ${ }^{164}$

The precautionary principle is not an endpoint but helps chart a course. The principle plots new directions for governance. No longer should regulators or the public have to demonstrate environmental harm before precautionary measures are required. No longer should technical experts and other professionals be the sole voices in deciding safety and acceptability. ${ }^{165}$ No longer should corporate and human interests automatically trump biodiversity values.

The principle also points directions for societal and technological change. Cleaner technologies, ${ }^{166}$ greater understanding and respect for nature and cultures, and less intrusive industrial approaches (such as organic agriculture, ecoforestry, and ecotourism) are called for. ${ }^{167}$

Given the broad policy implications to so many resource sectors, from aquaculture and fisheries to pollution control and to so many levels of governance (local, national, regional, and international), a major challenge will be to track the progress of the precautionary principle. ${ }^{168}$ This paper provides a partial gauging, but it remains to be seen how high the tides of precaution will be.

\section{Postscript}

The MOX Plant case between Ireland and the United Kingdom, having a Provisional Measures Order issued by the International Tribunal for the Law of the Sea on 3 December 2001 and proceeding to arbitration pursuant to Annex VII of the Convention of the Law of the Sea, ${ }^{169}$ may further develop the international jurisprudence relating to precaution. Ireland is challenging a United Kingdom decision to authorize and allow operation of a mixed oxide fuel facility in Sellafield adjacent to the Irish Sea. While various procedural and substantial arguments are being put forward, a central argument of Ireland is that the precautionary principle places the burden on the United Kingdom to demonstrate that no harm would arise from discharges and other consequences of operating the MOX plant.

The provisional measures stage of litigation did not result in detailed or conclusive judicial articulations regarding precaution. The Tribunal's Order did not enter into a discussion of the precautionary approach but merely noted in paragraph 84 that "prudence and caution require that Ireland and the United Kingdom cooperate in exchanging 
information concerning risks or effects of the operation of the MOX plant and in devising ways to deal with them. ..." The separate opinion of Judge Wolfrum noted that it is still a matter of discussion whether the precautionary principle/approach has become part of international customary law, and there is no general agreement as to the consequences flowing from the principle other than the burden of proof concerning the possible impact of a given activity being reversed. The separate opinion of Judge Treves regretted that the Tribunal had not been more explicit in giving reasons for deciding not to suspend commissioning of the MOX plant. Judge Treves indicated that an underlying reason for not substantively invoking the precautionary approach was:

[T]he scientific arguments brought by the parties did not focus precisely enough on whether the commissioning of the MOX plant could produce a significant increment, or the risk of a significant increment, of the radioactivity in the Irish sea during the few months before the Annex VII arbitral tribunal could be seized of a request concerning provisional measures. ${ }^{170}$

Judge Ad Hoc Székely, in a further separate opinion, was especially critical of the Tribunal's judgment in light of the precautionary principle. He found it surprising that the Tribunal, without any basis in law or science, gave the United Kingdom and not Ireland the benefit of the doubt regarding the risk of harm alleged by Ireland. However, he believed the procedural measures ordered by the Tribunal for further cooperation and consultations were based upon considerations deriving from a precautionary approach.

\section{Notes}

1. See generally, J. M. MacDonald, "Appreciating the Precautionary Principle as an Ethical Evolution in Ocean Management” (1995), 26 Ocean Dev. \& Int'l L. 255 and R. J. Wilder, "Law of the Sea Convention as Stimulus for Robust Environmental Policy: The Case for Precautionary Action" (1996), 12 Ocean Y.B. 207.

2. For good overviews, see D. Freestone and E. Hey, "Origins and Development of the Precautionary Principle" in D. Freestone and E. Hey (eds.), The Precautionary Principle and International Law: The Challenge of Implementation (The Hague: Kluwer Law International, 1996), at Chapter 1 and H. Hohmann, Precautionary Legal Duties and Principles of Modern International Environmental Law (London: Graham \& Trotman/Martinus Nijhoff, 1994).

3. For a review of the uses of the precautionary principle in international treaties, see C. Raffensperger and J. A. Tickner (eds.), Protecting Public Health \& The Environment: Implementing the Precautionary Principle (Washington, D.C.: Island Press, 1999), at Appendix B and J. Cameron, "The Precautionary Principle in International Law" in T. O'Riordan, J. Cameron, and A. Jordan (eds.), Reinterpreting the Precautionary Principle (London: Cameron May 2001), at Chapter 5 .

4. D. VanderZwaag, "The Precautionary Principle in Environmental Law and Policy: Elusive Rhetoric and First Embraces" (1999), 8 J. Env. L. \& Pract. 355 at 358.

5. See, e.g., D.M. Dzidzornu, "Four Principles in Marine Environmental Protection: A Comparative Analysis" (1998), 29 Ocean Dev. \& Int'1 L. 91; J. Van Dyke, "The Rio Principles and Our Responsibilities of Ocean Stewardship" (1996), 31 Ocean \& Coastal Mgm't 1; and D. VanderZwaag, Canada and Marine Environmental Protection: Charting a Legal Course Towards Sustainable Development (London: Kluwer Law International, 1995), at Chapter 1.

6. See, e.g., J. Cameron and J. Abouchar, "The Precautionary Principle: A Fundamental Principle of Law and Policy for the Protection of the Environment" (1991), 14 B. C. Int'1 \& Comp. L. Rev. 1.

7. See, C. F. Cranor, "Asymetric Information, the Precautionary Principle and Burdens of Proof" in Raffensperger and Tickner, supra note 3, Chapter 4. 
8. See, e.g., L. Gündling, "The Status in International Law of the Principle of Precautionary Action" (1990), 5 Int'l J. Estuarine \& Coastal L. 23.

9. C.D. Stone, "Is There a Precautionary Principle?" (2001), 31 Env. L. Reptr. 10790.

10. For a review of various national approaches, see Cameron and Abouchar, supra note 6; D. VanderZwaag, CEPA and the Precautionary Principle/Approach, Reviewing CEPA: The Issues \#18 (Ottawa: Minister of Supply and Services, 1994); and O'Riordan et al. supra note 3, Chapter 7 (Netherlands), Chapter 8 (United States), Chapter 9 (Australia), and Chapter 10 (Canada).

11. Over 40 cases relating to the precautionary principle have been decided in Commonwealth jurisdictions alone. For a review of some of the cases see VanderZwaag, supra note 4, at 373-74; W. Th. Douma, "The Precautionary Principle," http://www.asser.nl/EEL/virtue/precprin.htm (date accessed: 27 June 2001); R. Unger, "Brandishing the Precautionary Principle Through the Alien Tort Claims Act" (2001), 9 N.Y.U. Env. L. J. 638 at 664-65; and E. Fisher, "Is the Precautionary Principle Justiciable?’ (2001), 13 J. Env. L. 315.

12. See WTO Appellate Body Report on EC Measures Concerning Meat and Meat Products (Hormones), WTO Doc. WT/DS26/AB/R (16 January 1998). For a review of the case, see L. Hughes, "Limiting the Jurisdiction of Dispute Settlement Panels: The WTO Appellate Body Beef Hormone Decision" (1998), 10 Geo. Int'l Env. L. Rev. 915.

13. Code of Conduct for Responsible Fisheries (Rome: Food and Agriculture Organization of the United Nations, 1995).

14. See D. Freestone, "Implementing Precaution Cautiously: The Precautionary Approach in the Straddling and Highly Migratory Fish Stocks Agreement" in E. Hey (ed.), Developments in International Fisheries Law (The Hague: Kluwer Law International, 1999), at Chapter 11.

15. See, e.g., E. Hey, "The Precautionary Concept in Environmental Policy and Law: Institutionalizing Caution" (1992), 4 Geo. Int'l Env. L. Rev. 303.

16. June 14, 1992, 31 I.L.M. 874 (1992).

17. The Declaration in Principle 15 calls for a precautionary approach.

18. See, e.g., VanderZwaag, supra note 10.

19. For a further review of the various wordings and approaches, see D. McIntryre and T. Mosedale, "The Precautionary Principle as a Norm of Customary International Law" (1997), 9 J. Env. L. 221 at $224-231$.

20. Principle 15, supra notes 16 and 17 .

21. Paragraph XVI(1), reprinted in 27 I.L.M. 835 (1988), at 840.

22. The wording partly reflects the concept of differential standards whereby developing states in particular should not be subject to the same environmental standards as developed states.

23. A. Jordan and T. O'Riordan, "The Precautionary Principle in Contemporary Environmental Law and Politics" in Raffensperger and Tickner, supra note 3, at 24.

24. For example, various types of proof are possible, such as having to prove a substance is "safe" or poses "no serious risk of harm." Cranor, supra note 7, at 93-94. Various evidentiary standards are also possible, such as beyond a reasonable doubt and on the balance of probabilities. Ibid. 82-86.

25. The concept of "margin of safety" is particularly evident in the United States's environmental laws, for example, U.S. national ambient air quality standards must be set "allowing an adequate margin of safety" and water pollution standards for toxic pollutants must provide an "ample margin of safety." See F. B. Cross, "Paradoxical Perils of the Precautionary Principle" (1996), 53 Wash. \& Lee L. Rev. 851, at 855.

26. Some authors have, indeed, lamented against the "playing it safe" mentality of precaution and have argued in favor of expanding human knowledge, wealth, and ingenuity for coping with future adversities. See, e.g., R. Brunton, "The Precautionary Principle: The Greatest Risk of All," Environmental Backgrounder No. 20 (Jolimont, Victoria, Australia, Institute of Public Affairs Ltd., Environmental Policy Unit, May 20, 1994) and J. N. Hathcock, "The Precautionary Principle-An Impossible Burden of Proof for New Products," http://www.agbioforum.org/ vol3no4ar13hathcock.htm (date accessed: 7 November 2001).

27. For an overview of practical implications of precaution, see A. Deville and R. Harding, Applying the Precautionary Principle (Sydney, Australia: The Federation Press, 1997). 
28. Protocol to the Convention on the Prevention of Marine Pollution by Dumping Wastes and Other Matter, 1972, LC/SM1/6 (14 November 1996); 36 I.L.M. 1 (1997).

29. December 29, 1972, 11 I.L.M. 1294 (1972).

30. Those wastes include dredged material; fish wastes; ships, aircraft, platforms, and other structures to the extent they do not pose a serious obstacle to fishing or navigation; inert, inorganic geological matter; uncontaminated organic matter of natural origin; and bulky substances primarily composed of iron, steel, concrete, or other similar matter that do not have a significant adverse effect.

31. The 1996 Protocol calls upon countries to require ocean disposal applicants to undertake waste prevention audits and to develop waste prevention strategies before permit issuance.

32. See R. M. M'Gonigle, T. L. Jamieson, M. K. McAllister, and R. M. Peterman, "Taking Uncertainty Seriously: From Permissive Regulation to Preventative Design in Environmental Decision Making" (1994), 32 Osgoode Hall L. J. 99, at 150-155.

33. Deville and Harding, supra note 27, at 71.

34. Public participation rights might be fostered in various ways including environmental rights of action and provision for participant funding. J. Moffet, "Legislative Options for Implementing the Precautionary Principle" (1997), 7 J. Env. L. \& Pract. 157, at 168.

35. For discussions, see J. Cooke and M. Earle, "Towards a Precautionary Approach to Fisheries Management" (1993), 2 RECIEL 252; S. M. Garcia, "The Precautionary Principle: Its Implications in Capture Fisheries Management" (1994), 22 Ocean \& Coastal Mgm't 99; G. J. Hewison, "The Precautionary Approach to Fisheries Management: An Environmental Perspective" (1996), 11 Int'l J. Marine \& Coastal L. 301; and D. V. Gordon and G. R. Munro, Fisheries and Uncertainty: A Precautionary Approach to Resource Management (Calgary: University of Calgary Press, 1996).

36. For a review of human value and interest conflicts over potential risks associated with increased Arctic shipping, see D. L. VanderZwaag and C. Lamson (eds.), The Challenge of Arctic Shipping: Science, Environmental Assessment and Human Values (Montreal \& Kingston: McGillQueen's University Press, 1990).

37. VanderZwaag, supra note 4 , at 361 .

38. A prime route for further operationalizing precaution may be through expanded recognition of a healthy environment in national legislation and constitutions and international instruments or through judicial interpretation of closely related human rights, such as the right to life or the right of indigenous peoples to protect their traditional way of life. For a review of international developments in the area, see M. T. Kamminga, "The Precautionary Approach in International Human Rights Law: How It Can Benefit the Environment" in D. Freestone and E. Hey (eds.), The Precautionary Principle and International Law: The Challenge of Implementation (London: Kluwer Law International, 1996), at Chapter 10.

39. VanderZwaag, supra note 4, at 361. An additional area of potential confusion or at least complexity is the variation in categorizing value perspectives. See generally, D. Scholsberg, Environmental Justice and the New Pluralism: The Challenge of Difference for Environmentalism (Oxford: Oxford University Press, 1999).

40. See A. Jordan, "The Precautionary Principle in the European Union” in O'Riordan, et al., supra note 3, 149-155 and C. F. Runge, G.-L. Bagnara, and L. A. Jackson, "Differing U.S. and European Perspectives on GMOs: Political, Economic and Cultural Issues" (2001), 2 Estey Centre J. Int'l L. \& Trade Pol'y 221.

41. For discussions see, M. W. Brombacher, "The Precautionary Principle Threatens to Replace Science" (Summer 1999) Pollution Engineering 32; K. R. Foster, P. Vecchia, and M. H. Repacholi, "Science and the Precautionary Principle" (2000) 288:5468 Science 979; J. S. Gray and J. M. Bewers, "Towards a Scientific Definition of the Precautionary Principle" (1996), 32 Marine Pollution Bulletin 768; and K. Barrett and C. Raffensperger, "Precautionary Science" in Raffensperger and Tickner, supra note 3, Chapter 6.

42. G. A. Adams, "Enthralled with Modernity: The Historical Context of Knowledge and Theory in Development in Public Administration" (1992), 52 Public Administration Rev. 363.

43. See, e.g., D. Santillo, R. L. Stringer, P. A. Johnston, and J. Tickner, "The Precautionary 
Principle: Protecting Against Failures of Scientific Method and Risk Assessment" (1998), 36 Marine Pollution Bulletin 939; D. A. Brown, "After the Earth Summit: The Need to Integrate Environmental Ethics into Environmental Science and Law" (1992), 2 Env. Ethics 1; and K. Cooper, L. Vanderlinden, T. McClenaghan, K. Keenan, K. Khatter, P. Muldoon, A. Abelsohn, Environmental Standard Setting and Children's Health (Toronto: Canadian Environmental Law Association and Ontario's College of Family Physicians, 2000), at Chapter 4.

44. The Biosafety Protocol leaves considerable ambiguity over the relationship of international trade agreements and whether a risk assessment is a precondition for a country of import intent on prohibiting importation of a genetically modified food. See, e.g., S. McCaffrey, "Biotechnology: Some Issues of General International Law” (2001), 14 Transnat'l Law 91; M. Victor, "Precaution or Protectionism? The Precautionary Principle, Genetically Modified Organisms, and Allowing Unfounded Fear to Undermine Free Trade" (2001), 14 Transnat'l Law. 295; A. Szekely, "Modified Organisms and International Law: An Ethical Perspective" (2001), 14 Transnat'l Law. 129; and H.-J. Priess and C. Pitschas, "Protection of Public Health and the Role of the Precautionary Principle under WTO Law: A Trojan Horse before Geneva's Walls?” (2000), 24 Fordham Int'l L.J. 519.

45. For recent discussions see D. Katz, "The Mismatch Between the Biosafety Protocol and the Precautionary Principle (2001), 13 Geo. Int'l Env. L. Rev. 949 and M. Geistfeld, "Reconciling Cost-Benefit Analysis with the Principle That Safety Matters More Than Money" (2001), 76 N.Y.U. L. Rev. 114.

46. A number of authors have highlighted the major limits of social and economic feasibility to precautionary action. See, e.g., V. Dethlefsen, "Marine Pollution Mismanagement: Towards the Precautionary Concept" (1986), 17 Marine Pollution Bulletin 54 and D. Ellis, "The Precautionary Principle: A Taxpayers' Revolt” (1993), 26 Marine Pollution Bulletin 170.

47. That is not to deny the possibility that industrial proponents may also promote environmental values. See D. B. Spence, "Paradox Lost: Logic, Morality, and the Foundations of Environmental Law in the 21st Century" (1995), 20 Colum. J. Env. L. 145.

48. Moffet, supra note 34 , at $168-169$.

49. See D. VanderZwaag, "The Concept and Principles of Sustainable Development: 'RioFormulating' Common Law Doctrines and Environmental Laws” (1993), 13 Windsor Y.B. Access Just. 39, at 65-67.

50. Because of administrative cost questions and difficulties in modifying existing regulatory agency "turfs," governments may be hesitant to move quickly towards such innovations. For example, the Canadian House of Commons Standing Committee on Environment and Sustainable Development, in undertaking a major review of biotechnology regulation in Canada, stopped short of recommending a new "transgenics agency" because of questions such as whether potential conflicts of interest of existing line departments have resulted in inappropriate decisions. See Report of the Standing Committee on Environment and Sustainable Development, Biotechnology Regulation in Canada: A Matter of Public Confidence (November 1996).

51. See T. O'Riordan, "The Precautionary Principle and Civic Science" in O'Riordan et al., supra note 3, Chapter 4.

52. Request for an Examination of the Situation in Accordance with Paragraph 63 of the Court's Judgment of 20 December 1974 on the Nuclear Tests (New Zealand v. France) case, [1995] I.C.J. Rep. 288.

53. [1996] I.C.J. Rep. 226.

54. Ibid. at 502-506.

55. Case Concerning the Gabcíkovo-Nagymaros Project (Hungary/Slovakia), [1997] I.C.J. 7.

56. For a critique of the Court's hesitancy to further develop international environmental law relating to precaution, see I. L. Bostian, "Flushing the Danube: The World Court's Decision Concerning the Gabcíkovo Dam” (1998), 9 Col. J. Int'l Env. L. \& Pol’y 401 at 420.

57. Southern Bluefin Tuna (New Zealand v. France; Australia v. Japan), Provisional Measures Order of 27 August 1999, http://www.itlos.org/start2_en.html (date accessed: 1 December 2001).

58. Paragraph 77 of the Provisional Measures Order stated "[T]he parties should in the 
circumstances act with prudence and caution to ensure that effective conservation measures are taken to prevent serious harm to the stock southern bluefin tuna...."

59. Separate opinions of Judge Tullio Treves and Judge Ad Hoc Ivan Shearer.

60. Separate opinion of Judge Laing. For reviews of the cases, see D. Freestone, "Caution or Precaution: 'A Rose By Any Other Name ...'?’ (1999), 10 Y.B. Int'1 Env. L. 25 and D. M. Johnston, "Fishery Diplomacy and Science and The Judicial Function" (1999), 10 Y.B. Int'l Env. L. 33 .

61. L. Sturtz, "Southern Bluefin Tuna Case: Australia and New Zealand v. Japan" (2001), 28 Ecology L.Q. 455.

62. For an overview of additional marine environmental challenges, such as wetland losses, sewage pollution, and introduction of alien species, see IMO/FAO/UNESCO-IOC/WMO/WHO/ IAEA/UN/UNEP Joint Group of Experts on the Scientific Aspects of Marine Environmental Protection (GESAMP), A Sea of Troubles, Rep. Stud. GESAMP No. 70 (2001) at http://gesamp.imo.org/ no70/htm (date accessed: 5 November 2001).

63. N. Thongtham, "Precious, and Pressured, Coral Reefs" (2 July 2000) Bangkok Post, Outlook at 1 .

64. Ibid. While it may not yet be possible to determine conclusively the causal link between coral bleaching episodes and global climate change, in 1998, coral bleaching was unprecedented in severity over large areas of the world. See Intergovernmental Panel on Climate Change, Climate Change 2001: Impacts, Adaptation and Vulnerability, Chapter 6, "Coastal Zones and Marine Ecosystems," http://www.grida.no/climate/ipcc-tar/wg2/295.htm (date accessed: 5 November 2001).

65. Ibid.

66. Ibid., Technical Summary.

67. See F. Linden Churchill, "Arctic Warming: The Big Meltdown" (4 September 2000) 156:10 Time Magazine 24 at 25.

68. Arctic Monitoring and Assessment Programme, Arctic Pollution Issues: A State of the Arctic Environment Report (Oslo: Arctic Monitoring and Assessment Programme, 1997), at 161.

69. See, e.g., P. J. Michaels, "Computer Models, the Kyoto Protocol, and Reality" (March 2000) Env. \& Climate News, http://www.heartland.org/environment/mar00/reality.htm (date accessed: 23 June 2000) and B. Lomborg, The Skeptical Environmentalist: Measuring the Real State of the World (Cambridge: Cambridge University Press, 2001), at 258-287.

70. Intergovernmental Panel on Climate Change, Climate Change 2001: The Scientific Basis, Summary for Policymakers, http://www.grida.no/climate/ippc.tar/wg1/005.htm (date accessed: 5 November 2001).

71. May 9, 1992, 31 I.L.M. 849 (1992). Article 3(3) provides:

The Parties should take precautionary measures to anticipate, prevent or minimize the causes of climate change and mitigate its adverse effects. Where there are threats of serious or irreversible damage, lack of full scientific certainty should not be used as a reason for postponing such measures, taking into account that policies and measures to deal with climate change should be cost-effective so as to ensure global benefits at the lowest possible cost. To achieve this, such policies and measures should take into account different socio-economic contexts. . . .

72. December 10, 1997, 37 I.L.M. 22 (1998).

73. For example, U.S. greenhouse gas emissions have been projected to increase by some $23 \%$ by 2010 even though a $7 \%$ reduction in emissions was pledged from 1990 levels. S. Oberthür and H. E. Ott, The Kyoto Protocol: International Climate Policy for the 21st Century (Berlin: Springer-Verlag, 1999), at 18.

74. See Letter from President George W. Bush to Senators Hagel, Helms, Craig, and Roberts, reprinted in (2001), 31 Env. Pol'y \& L. 122.

75. FCCC/CP/2001/L.7 (24 July 2001). Various commitments were agreed to including the creation of three new funds to assist developing countries.

76. The Marrakesh Accords still leave considerable details to be developed regarding the flexibility mechanisms. For example, the executive board of the clean development mechanism is 
to develop and recommend simplified modalities and procedures to the Conference of the Parties (at its eighth session) for small-scale projects such as renewable energy and energy efficiency activities. The Subsidiary Body for Scientific and Technological Advice is to develop definitions and modalities for including forestation and reforestation projects under the clean development mechanism with the aim of adopting a decision at the ninth session of the Conference of the Parties. The Marrakesh Accords are available at http://www.unfccc.de/cop7/documents/ accords_draft.pdf (date accessed: 19 November 2001).

77. For a critique of climate change policies and the Protocol, see Lomborg, supra note 69, at $302-324$.

78. Arctic Monitoring and Assessment Programme, supra note 68, at 74-75.

79. For arguments that human fears may be exaggerated in light of other lifetime risks, see Lomborg, supra note 69, Chapter 22 "Our Chemical Fears."

80. For a summary of pollutant pathways, see K. Crane and J. L. Galasso, Arctic Environmental Atlas (Washington, DC and New York: Office of Naval Research Laboratory and Hunter College, 1999).

81. Arctic Monitoring and Assessment Programme, supra note 68, at 172.

82. For a more detailed discussion, see D. VanderZwaag "Land-based Marine Pollution and the Arctic: Polarities Between Principles and Practice" in D. Vidas (ed.), Protecting the Polar Marine Environment: Law and the Policy for Pollution Prevention (Cambridge: University Press, 2000), at Chapter 8.

83. September 11, 1998, 38 I.L.M. 1 (1999).

84. As of October 2001, the Convention, being implemented on an interim basis, covered 21 pesticides, five severely hazardous pesticide formulations, and five industrial chemicals. See Coverage of the Eighth Session of the Intergovernmental Negotiating Committee (INC) for an International Legally Binding Instrument for the Application of the Prior Informed Consent Procedure for Certain Hazardous Chemicals and Pesticides in International Trade (8 October 2001) 15:58 Earth Negotiations Bulletin, http://www.iisd.ca/linkages/chemicals/pic/pic8 (date accessed: 9 October 2001).

85. Status of Signature and Ratification at http://www.pic.int (date accessed: 8 November 2001).

86. For a critical review, see D. VanderZwaag, P. Wells, and J. Karau, "The Global Program of Action for the Protection of the Marine Environment from Land-Based Activities: A Myriad of Sounds, Will the World Listen?” (1998), 13 Ocean Y.B. 183.

87. May 23, 2001, 40 I.L.M. 532 (2001).

88. D. VanderZwaag, R. Huebert, and S. Ferrara, "The Arctic Environmental Protection Strategy, Arctic Council and Multilateral Environmental Initiatives: Tinkering While the Arctic Marine Environment Totters" in A. Oude Elferink and D. Rothwell (eds.), The Law of the Sea and Polar Maritime Delimitation and Jurisdiction (The Hague: Kluwer Law International, 2001), at Chapter 12.

89. Aldrin, chlordane, dieldrin, endrin, heptachlor, hexachlorobenzene, mirex, toxaphene, polychlorinated biphenyls, DDT, dioxins, and furans.

90. Supra note 87, Article. 3(1)(a) and Annex A, Part II.

91. Article 3(1)(b) and Annex B.

92. For example, chlordane, heptachlor, and mirex may be used as termiticides. Article 4 and Annex A.

93. Article 5.

94. A POPs Review Committee is to be established to evaluate additional chemicals for inclusion based on the criteria of toxicity, persistence, bioaccumulation, and long-range transport, but a rather cumbersome review process is set out in Article 8. However, the Convention does require the Conference of the Parties, taking account of the Committee's recommendations, to decide in a precautionary manner whether to list a chemical. Article 8(9).

95. See K. von Moltke, Whither MEAs? The Role of International Environmental Management in the Trade and Environmental Agenda (Winnipeg: International Institute for Sustainable 
Development, 2001) at 27; and GESAMP (IMO/FAO/UNESCO-IOC/WMO/ WHO/IAEA/UN/ UNEP Joint Group of Experts on the Scientific Aspects of Environmental Protection) and Advisory Committee on Protection of the Sea, Protecting the Oceans from Land-Based Activities: Land-Based Sources and Activities Affecting the Quality and Uses of the Marine, Coastal and Associated Freshwater Environment, Rep. Stud. GESAMP No. 71 (Nairobi: UNEP, 2001), at 22 and 122.

96. Anne Platt McGinn, "POPs Culture" (2000) 13:2 World Watch 26.

97. "Summary of Key Elements in the Global POP Treaty" (Prepared by WWF's Global Toxic Chemicals Initiative) at http://www.ipen.org/treaty03.html (date accessed: 27 January 2001).

98. United Nations Environment Programme, Decisions Adopted by the Governing Council at Its Twenty-First Session (9 February 2001), http://www.unep.org/gc_21st/ (date accessed, 1 December 2001).

99. Numerous factors have been suggested as contributing to the fisheries management failures including lack of political resolution, persistence of subsidies, lack or control by flagstates of their fleets, lack of authority of fisheries bodies, disregard of scientific advice, limited consideration of community management, lobbying by industrial lobbies, and insufficient implementation capacity, especially in small island nations. See S. M. Garcia and R. Grainger, "Fisheries Management and Sustainability: A New Perspective of an Old Problem?" in D. A. Hancock, D. C. Smith, A. Grant, and J. P. Beumer (eds.), Developing and Sustaining World Fisheries Resources: The State of Science and Management (Collingwood, Victoria: CSIRO Publishing, 1997), at 650 .

100. For an excellent review of the challenges, see S. M. Kaye, International Fisheries Management (The Hague: Kluwer Law International, 2001), at Chapter 5.

101. Of fished stocks accounting for world marine fish landings, $5 \%$ have been reported as depleted, $11 \%$ overexploited, $1 \%$ recovering, $36 \%$ fully exploited with $25 \%$ of stocks not being assessed. FAO, Review of the State of World Fishery Resources: Marine Fisheries (FAO Fish. Circ. 929) (1997) as discussed in M. V. Gupta "Perspectives on Aquatic Genetic Resources in Asia and the Pacific" in R. S. V. Pullin, D. M. Bartley, and J. Kooiman (eds.), Towards Policies for Conservation and Sustainable Use of Aquatic Genetic Resources (Manila, Philippines: International Centre for Living Aquatic Resources Management, 1999), at 101.

102. See FAO, Report of the Technical Consultation on Illegal, Unreported and Unregulated Fishing, Rome, 2-6 October 2000, FAO Fisheries Report No. 634 (Rome: Food and Aquaculture Organization of the United Nations, 2000).

103. (20 March 2000) available at http://www.un.org/Depts/los/A55-61.htm (date accessed: 8 March 2001), at para. 120.

104. Supra note 13. For an overview see G. Moore, "The Code of Conduct for Responsible Fisheries" in Hey, supra note 14, at Chapter 5.

105. Precautionary Approach to Capture Fisheries and Species Introductions, FAO Technical Guidelines for Responsible Fisheries No. 2 (Rome: Food and Agriculture Organization, 1996).

106. Ibid., at para. $6(\mathrm{f})(\mathrm{g})$.

107. Ibid., at para. $6(\mathrm{~h})$.

108. Ibid., at para. 7(d).

109. Ibid., at para. 7(b).

110. Agreement for the Implementation of the Provisions of the United Nations Convention on the Law of the Sea of 10 December 1982 Relating to the Conservation and Management of Straddling Fish Stocks and Highly Migratory Fish Stocks, 34 I.L.M. 1542 (1995).

111. Ibid., at Article 6 and Annex II.

112. For a review of the main focus of developing reference points in such fora as the International Council for Exploration of the Sea (ICES) and NAFO, and a similar fixation within the International Commission for the Conservation of Atlantic Tunas (ICCAT), see Report of the Meeting of the ICCAT Ad Hoc Working Group on the Precautionary Approach, COM-SCRS/99/ 11 (Dublin, Ireland 17-21 May 1999). Also see the collection of papers in V. R. Restrepo (ed.), Proceedings of the Fifth National NMFS Stock Assessment Workshop: Providing Scientific Ad- 
vice to Implement the Precautionary Approach Under the Magnuson-Stevens Fishery Conservation and Management Act, NOAA Tech. Memo., NMFS-F/SPO-40 (U.S. Dept. of Commerce, June 1999). For a detailed overview of precautionary discussions and initiatives in various international and regional organizations, see S. M. Garcia, "The Precautionary Approach to Fisheries 1995-2000: Progress Review and Main Issues," in M. H. Nordquist and J. M. Moore (eds.), Current Fisheries Issues and the Food and Agriculture Organization (The Hague: Martinus Nijhoff Publishers, 2000), at 479-560.

Not all precautionary discussions have been narrow, for example, the North Atlantic Salmon Conservation Organization (NASCO) in June 1998 accepted an Agreement on Adoption of a Precautionary Approach, which calls for numerous actions, including stock rebuilding programs and habitat improvements. The Agreement is available at http://www. nasco.org.uk/html/ agreement_on_adoption_of_apre.html (date accessed: 9 March 2001).

113. A strong version of precaution might require a fishery proponent to establish no adverse impacts on essential fish habitat. See M. Territo, "The Precautionary Principle in Marine Fisheries Conservation and the U.S. Sustainable Fisheries Act of 1996" (2000), 24 Vt. L. Rev. 1351 , at 1373 .

114. While the precautionary approach does seek to reverse the burden of proof traditionally on fisheries managers to show conservation need before imposing more stringent management measures, implementation is being thwarted by modelling uncertainties, lack of data and domination of the scientific field by the biological sciences. See L. J. Richards and J.-J. Maguire, "Recent International Agreements and the Precautionary Approach: New Directions for Fisheries Management Science" (June 1998) 55:6 Can. J. Fisheries \& Aquatic Sciences 1545.

115. Regarding the need to overcome political opposition to environmental commitment, see D. M. Johnston and D. L. VanderZwaag, "The Ocean and International Environmental Law: Swimming, Sinking, and Treading Water at the Millennium" (2000), 43 Ocean \& Coastal Mgm't 141 , at $147-149$.

116. For a critique of the unrelenting faith in scientific risk assessment and expert systems, see M. O'Brien, Making Better Environmental Decisions: An Alternative to Risk Assessment (Cambridge, MA: The MIT Press, 2000).

117. See, e.g., A Geisinger, "Sustainable Development and the Domination of Nature: Spreading the Seed of the Western Ideology of Nature" (1999), 27 B. C. Env. Aff. L. Rev. 43.

118. See generally, W. Lang, "From Environmental Protection to Sustainable Development: Challenges for International Law" in W. Lang (ed.), Sustainable Development and International Law (London: Graham \& Trotman/Martinus Nijhoff, 1995), at Chapter 17.

119. See P. Sands, "International Law in the Field of Sustainable Development: Emerging Legal Principles" in Lang, supra note 118, at Chapter 5.

120. The Rio Declaration in fact avoids rights terminology, perhaps demonstrating the continuing uncertainty over human rights law in the development of international environmental law. Principle 1 of the Rio Declaration states: "Human beings are at the center of concerns for sustainable development. They are entitled to a healthy and productive life in harmony with nature." See A. Boyle, "The Role of International Human Rights Law in the Protection of the Environment," in A. E. Boyle and M. A. Anderson (eds.), Human Rights Approaches to Environmental Protection (Oxford: Clarendon Press, 1996), at 43.

121. For reviews, see E. Brandl and H. Bungert, "Constitutional Entrenchment of Environmental Protection: A Comparative Analysis of Experiences Abroad" (1992), 16 Harv. Env. L. Rev. 1 and J. P. Eurick, "The Constitutional Right to a Healthy Environment: Enforcing Environmental Protection through State and Federal Constitutions" (2001), 11 Int'l Legal Perspectives 185.

122. See, e.g., J. Lee, "The Underlying Legal Theory to Support a Well-Defined Human Right to a Healthy Environment as a Principle of Customary International Law" (2000), 25 Colum. J. Env. L. 283; P. E. Taylor, "From Environmental to Ecological Human Rights: A New Dynamic in International Law?” (1998), 10 Geo. Int'1 Env. L. Rev. 309; E. M. Kornicker Uhlmann, "State Community Interests, Jus Cogens and Protection of the Global Environment: Developing 
Criteria for Preemptory Norms" (1998), 11 Geo. Int'1 Env. L. Rev. 101; and M. Leighton Schwartz, "International Legal Protection for Victims of Environmental Abuse" (1993), 18 Yale J. Int'l L. 355.

123. December 19, 1966, 999 U.N.T.S. 171; reprinted in W. J. F. M. van der Wolf (ed.), Human Rights Selected Documents (Boxtel, The Netherlands: Global Law Association, 1994) 48-61, at Articles 6 and 9. For a discussion of the relationship between the right to life and the right to a safe environment, see B. G. Ramcharan, "The Concept and Dimensions of the Right to Life" in B. G. Ramcharan (ed.), The Right to Life in International Law (Dordrecht: Martinus Nijhoff Publishers, 1985), at 13-14.

124. December 19, 1966, 993 U.N.T.S. 3; reprinted in ibid., at 40-47, at Article 12. The Committee on Economic, Social and Cultural Rights at its 22nd session in 2000 acknowledged that the right to health extends to the underlying determinants of health, such as access to safe water and adequate sanitation, safe and healthy working conditions, and a healthy environment. See United Nations, International Human Rights Instruments: Compilation of General Comments and General Recommendations Adopted by Human Rights Treaty Bodies, U.N. Doc. HRI/GEN/ 1/Rev. 5 (26 April 2001) at 90-91, General Comment No. 14.

125. UN Commission on Human Rights, Sub-Commission on Prevention of Discrimination and Protection of Minorities, Review of Further Developments in Fields with which the SubCommission Has Been Concerned, Human Rights and the Environment, Final Report of the Special Rapporteur, Mrs. Fatma Zohra Ksentini, UN Doc.E/CN.4/Sub.2/1994/9 (1994) Annex I, reprinted in Boyle, supra note 120, at 65-69. For a review of the political process, see A. Fabra Aguilar and N. A. Popovic, "Law-Making in the United Nations: The UN Study on Human Rights and the Environment" (1995), 3 RECIEL 197 and N. A. F. Popovic, "In Pursuit of Environmental Human Rights: Commentary on the Draft Declaration of Principles on Human Rights and the Environment" (1996), 27 Colum. Hum. Rts. L. Rev. 487.

126. See, e.g., A. Fijalkowski and M. Fitzmaurice (eds), The Right of the Child to a Clean Environment (Aldershot, England: Dartmouth Publishing Company Ltd. and Ashgate Publishing Ltd., 2000).

127. November 20, 1989, 28 I.L.M. 1448 (1989); reprinted in Maria Rita Saulle (ed.), The Rights of the Child: International Instruments (Irving-on-Hudson, New York: Transnational Publishers Inc., 1995), 9-29.

128. Ibid., at 18.

129. For a recent overview, see F. Trippett, “Towards a Broad-Based Precautionary Principle in Law and Policy: A Functional Role for Indigenous Knowledge Systems (TEK) Within Decision-Making Structures" (LL.M. thesis, unpublished, Dalhousie Law School, Halifax, Nova Scotia, 2000).

130. Numerous articles have discussed emerging indigenous rights relating to the environment. See, e.g. B. J. Richardson, "Indigenous Peoples, International Law and Sustainability" (2001), 10 RECIEL 1; A. Meyer, "International Environmental Law and Human Rights: Towards the Explicit Recognition of Traditional Knowledge" (2001), 10 RECIEL 37; S. J. Anaya, "Environmentalism, Human Rights and Indigenous Peoples: A Tale of Converging and Diverging Interests" (1999), 7 Buffalo Env. L. J. 1; S. H. Venne, Our Elders Understand Our Rights: Evolving International Law Regarding Indigenous Peoples (Penticton, British Columbia: Theytus Books Ltd., 1998); J. Paulo Kastrup, "The Internationalization of Indigenous Rights from the Environmental and Human Rights Perspective" (1997), 32 Tex. Int'l L.J. 97; H. M. Osofsky, "Environmental Human Rights Under the Alien Tort Statute: Redress for Indigenous Victims of Multinational Corporations" (1997), 20 Suffolk Transnat'l L. Rev. 335; F. H. Naqvi, "People's Rights or Victim's Rights: Reexamining the Conceptualization of Indigenous Rights in International Law" (1996), 71 Indiana L. J. 673; W. M. Reisman, "Protecting Indigenous Rights in International Adjudication" (1995), 89 Am. J. Int'1 Law 350; and R. K. Hitchcock, "International Human Rights, the Environment and Indigenous Peoples” (1994), 5 Colo. J. Env. L. \& Pol'y 1.

131. For a useful listing, including such rights as self-determination, intellectual property, cultural property, protection of cultural heritage, and recognition of customary law and practice, 
see D. A. Posey, "Developing Sui Generis Options for the Protection of Living Aquatic Resources of Indigenous and Local Communities" in Pullin et al., supra note 101, at 187, 195-196.

132. June 5, 1992, 31 I.L.M. 818 (1992), at Article 8.

133. UN Doc. E/CN.4/Sub.2/1994/2/Add.1 (1994).

134. Ibid. The Draft Declaration has been subject to ongoing discussion and debates with a working group established by the Commission on Human Rights to further elaborate a draft for consideration and adoption by the General Assembly. One of the points of controversy has been the scope of the right of self-determination. See Commission on Human Rights, Report of the Working Group Established in Accordance with Commission on Human Rights Resolution 1995/ 32, UN Doc. E/CN.4/2001/85 (2001).

135. See M. Mutua, "Savages, Victims, and Saviors: The Metaphor of Human Rights" (2001), 42 Harv. Int'l L. J. 201.

136. See K. Tomasevski, "Environmental Rights” in A. Eide, C. Krause and A. Rosas (eds.), Economic, Social and Cultural Rights: A Textbook (Dordrecht: Martinus Nijhoff Publishers, 1995), at Chapter 17.

137. For a review of some of the difficulties see, M. A. Anderson, "Human Rights Approaches to Environmental Protection: An Overview" in Boyle and Anderson, supra note 120, at Chapter 1.

138. See, e.g., Kamminga, supra note 38. On the general need to link human rights law with other branches of international law, see C. Chinkin, "International Law and Human Rights," in T. Evans (ed.), Human Rights Fifty Years On: A Reappraisal (Manchester: Manchester University Press, 1998), at Chapter 5.

139. See, generally, Cooper et al., supra note 43, at 164-65; and D. Santillo, P. Johnston, and A. Singhofen, The Way Forward Out of the Chemicals Crisis: An Alternative, Precautionary Approach to the Regulation of the Manufacturing, Marketing and Use of Chemicals in Europe (Brussels: Greenpeace International, 1999).

140. For example, with the International Covenant of Civil and Political Rights, the Human Rights Committee will not entertain individual complaints unless the state against whom the allegation is raised has ratified both the Convention and the Covenant's First Optional Protocol. L. Heffernan, "A Comparative Review of Individual Petition Procedures under the European Convention on Human Rights and the International Covenant on Civil and Political Rights" (1997), 19 Hum. Rts. Q. 78. The Convention on the Rights of the Child lacks an individual petitioning system. G. Van Bueren, "Of Minors and Minorities," in D. Fottrell and B. Bowring (eds.), Minority and Group Rights in the New Millinnium (The Hague: Martinus Nijhoff Publishers, 1999), at Chapter 3.

141. For a comparative review of human rights jurisprudence at the national level, see S. M. Beatty (ed.), Human Rights and Judicial Review: A Comparative Perspective (Dordrecht: Martinus Nijhoff Publishers, 1994).

142. In Baker v. Canada (Minister of Citizenship and Immigration), [1999] 2 S.C.R. 817, the Court set aside an immigration officer's decision to deport Marvis Baker a citizen of Jamaica who never received permanent resident status and lived illegally in Canada for 11 years. Even though Baker had four children born in Canada, the immigration officer decided there were insufficient humanitarian and compassionate grounds to warrant a residency application to be made in Canada. The Court, referring to the rights of the child in the Convention on the Rights of the Child and the UN Declaration on the Rights of the Child, found the official's exercise of deseretion to be unreasonable. Even though the Convention had not been implemented by Parliament, the Court stated: "[T]he values reflected in international human rights law may help inform the contextual approach to statutory interpretation and judicial review." Ibid. at 861. In 114957 Canada Ltée (Spraytech Société d' arrosage) v. Hudson (Town), [2000] S.C.J. No. 42, the Supreme Court of Canada upheld a municipal by-law partially prohibiting pesticides and found that a finding of statutory authorization was consistent with the precautionary principle of international law and policy. For a review of the case, see H. Epstein, "Case Comment: Spraytech v. Town of Hudson" (2001), 19 M.P.L.R. 3d 56. 
143. For an analysis of the challenges raised by the process of translating international law to the national level, see K. Knop, "Here and There: International Law in Domestic Courts" (2000), 32 Int'l Law \& Politics 501.

144. On the need for an incremental approach to clarifying the specific legal implications of sustainable development, see G. Handl, "Sustainable Development: General Rules versus Specific Obligations", in Lang, supra note 118, at Chapter 4.

145. On the potential interrelationships, see M. D. Young, "For Our Childrens' Children: Some Practical Implications of Inter-Generational Equity and the Precautionary Principle," Occasional Publication No. 6 (Canberra: Australian Government Publishing Services, 1993).

146. The principle is especially welcome to those discontent with authoritarian assurances and individuals excluded from elite policy making. A Bernstein, "Precaution and Respect" in Rafensperger and Tickner, supra note 3, Chapter 8, at 154. On the need for a participatory forum at the global level to further work out the concrete implications of sustainable development and precaution in the field of biotechnology, see S. D. Murphy, "Biotechnology and International Law" (2001), 42 Harv. Int'l L.J. 47 at 132.

147. R. M. M'Gonigle, "The Political Economy of Precaution” in Raffensperger and Tickner, supra note 3, Chapter 7, at 141-142.

148. Assurance bonding, where a polluter would receive back a bond if damage does not occur, may also support investment in safer alternatives. J. A. Tickner, "A Map Toward Precautionary Decision Making" in Raffensperger and Tickner, supra note 3, Chapter 9, at 173.

149. FAO Technical Guidelines for Responsible Fisheries No. 3 (Rome: FAO, 1996).

150. Such as the need to fully consider the benefits that will be foregone by a development, for example, the various values lost in destruction of a mangrove area. Ibid., at para. 55.

151. Ibid., para. 57.

152. See Kaye, supra note 100, Chapter 6, "Ecosystem Management and International Fisheries," at 273-74.

153. For example, Article 6.2 of the FAO Code of Conduct for Responsible Fisheries, supra note 13, urges management measures that "not only ensure the conservation of target species but also of species belonging to the same ecosystem or associated with or dependent upon the target species." For a further discussion of international legal provisions and constraints for protecting ecosystem diversity, see D. K. Anton, "Law for the Sea's Biological Diversity" (1997), 36 Colum. J. Transnat'l Law 341.

154. M. J. Tegner and P. K. Dayton, "Ecosystem Effects of Fishing in Kelp Forest Communities" (2000), 57 ICES J. Marine Science 579.

155. See M. P. Sissenwine and P. M. Mace, "Governance for Responsible Fisheries: An Ecosystem Approach," presented at the Reykjavik Conference on Responsible Fisheries in the Marine Ecosystem, Reykjavik, Iceland, 1-4 October 2001, available at ftp://ftp.fao.org/fi/document/reykjavik/default.htm (date accessed: 10 November 2001).

156. Article 194(5) of the Law of the Sea Convention specifically calls for measures necessary to protect rare or fragile ecosystems as well as the habitat of depleted, threatened, or endangered species and other forms of marine life. December 10, 1982, U.N. Doc. A/CONF.62/122 (1982); 21 I.L.M. 1261 (1982).

157. On the importance of sustainable development in integrating principles from international environmental law, international human rights law, and international economic law, see D. McGoldrick, "Sustainable Development and Human Rights: An Integrated Conception" (1996), 45 Int'l \& Comp. L. Q. 796.

158. J. B. Buhl, "Sustainable Development: A Five-Dimensional Algorithm for Environmental Law" (1999), 18 Stan. Env. L. J. 31. Regarding the multiple dimensions of sustainability, see A. Charles, Sustainable Fishery Systems (Oxford: Blackwell Science, 2001), at 188-191.

159. Hungary/Slovakia, supra note 55, at 90.

160. Ibid., at 92.

161. [1996] NZRMA 97.

162. [1999] NZRMA 209. 
163. M'Gonigle, supra note 147 , at 127.

164. For arguments in favor of such an organization, see F. Biermann, "The Case for a World Environment Organization" (November 2000) 42:9 Environment 22.

165. For a call for inclusionary, multistakeholder environmental planning in light of the precautionary principle, see R. W. Collin and R. M. Collin, "Sustainability and Environmental Justice: Is the Future Clean and Black?" (2001), 31 Env. L. Rept. 10968.

166. K. Geiser, "Cleaner Production and the Precautionary Principle" in Raffensperger and Tickner, supra note 3, Chapter 20.

167. M'Gonigle, supra note 147, at 142.

168. For a further progress review, see J. M. Van Dyke, "The Evolution and International Acceptance of the Precautionary Principle," paper prepared for the global conference "Oceans and Coasts at Rio + 10: Toward the 2002 World Summit on Sustainable Development-Assessing Progress, Addressing Continuing and New Challenges," UNESCO, Paris, 3-7 December 2001, http://www.udel.edu/CMS/csmp/rio+10 (date accessed: 14 November 2001).

169. The Provisional Measures Order of the International Tribunal for the Law of the Sea and all the judicial opinions are available at http:www.itlos.org/start2_en.htm/ (date accessed, 17 December 2001).

170. Separate Opinion of Judge Tullio Treves, para. 8. 